Research Article

\title{
Factors Affecting Use of Formal Agricultural Credit among Smallholder Farmers in Western Nepal
}

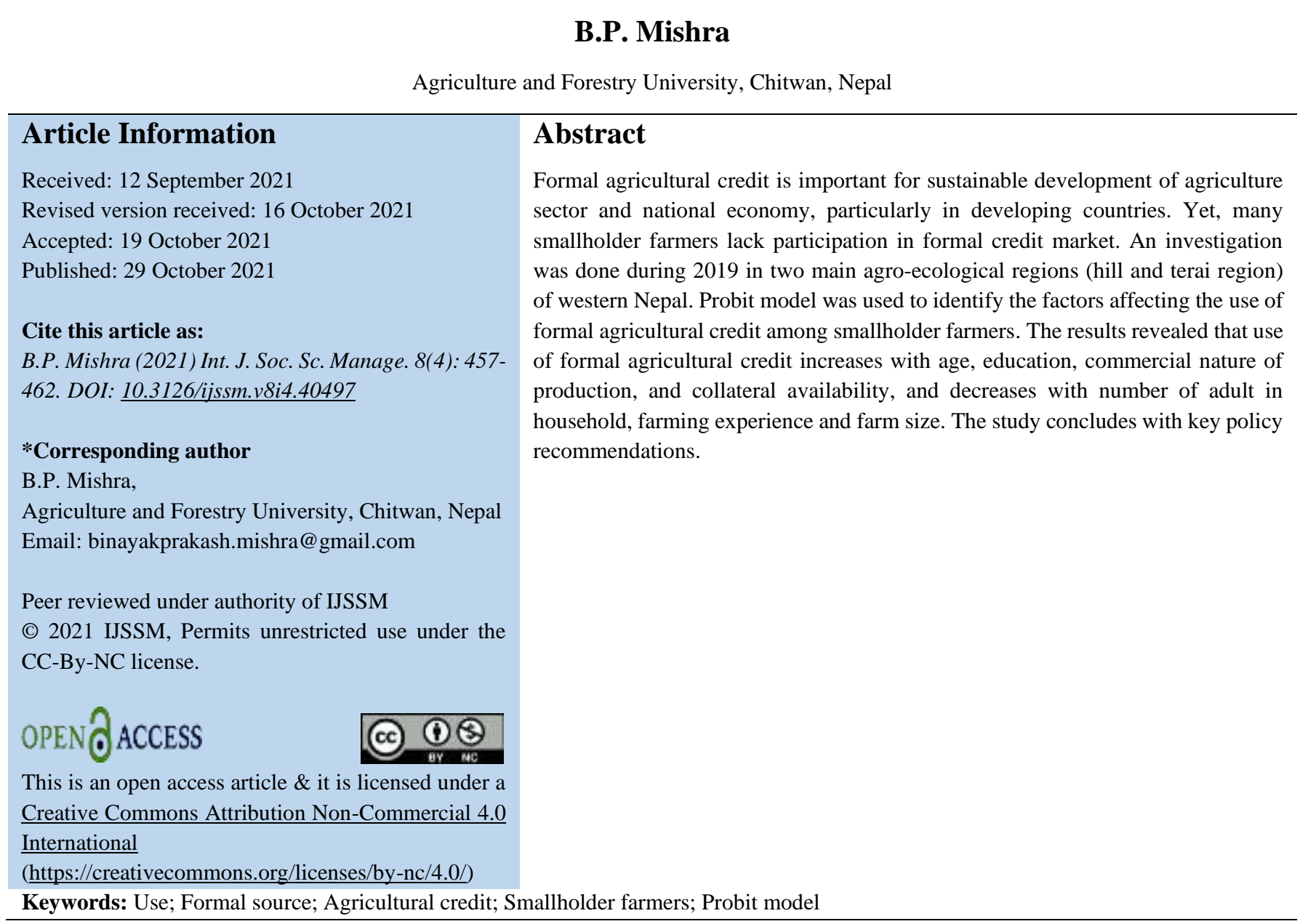

\section{Introduction}

More than half of the Nepalese farmers are practicing agriculture in less than 0.5 ha farmland (CBS, 2011). These smallholder farmers are mostly resource poor farmers and their ability to make investments in farm is quite low. There is a huge gap between owned capital and required capital for sustaining agricultural practices among smallholder farmers (Lemessa and Gemechu, 2016). With low investment in farm technology, smallholder farmers lack new improved inputs and technology in farming resulting low productivity in agriculture (Oni et al., 2009).
Agricultural credit is an essential facilitator for proper access to improved agricultural technology in the present context. Smallholder farmers are using agricultural credit from formal sources and informal sources. Formal sources include banks, cooperatives and financial institutions while informal sources include friends, relatives, neighbors and professional money lenders. Formal credit market is recommended over informal credit because formal institutions are safe as they are regulated by the government and eventually government receives economic benefits 
from transactions of formal credit which aid in economic development of the country. Government has no or little knowledge about the transaction of informal credit markets as it falls outside the domain of legal system and such transactions only help to make certain individuals richer. Therefore, informal credit market should be absorbed into the formal sector during the financial development process because they play a negative role in economic development (Mohieldin and Wright, 2000). In the meantime, government should restrict the activities of informal credit market (Goldsmith, 1969; McKinnon, 1973; Shaw, 1973). This has been realized over time and to make sustainable development in agriculture and national economy, different formal institutions are providing easy and quick access to agricultural credit at lower rates than informal sources. However, the participation of smallholder farmers in obtaining formal agricultural credit is still low. Hence, this paper attempts to identify the factors affecting the use of formal agricultural credit among smallholder farmers.

\section{Methodology}

\section{Study Area}

The study was done during 2019 in Lamjung and Nawalpur district of western Nepal representing two main agroecological regions of Nepal (hill and terai). Formal institutions are well functioning in these districts to provide agricultural credit. The surveyed municipalities in Lamjung district of hill region include Sundarbazar, Rainas and Besisahar. The surveyed municipalities in Nawalpur district of terai region include Devachuli, Madhyabindu and Kawasoti.

\section{Sampling Technique}

The districts were selected purposively to represent two main agro-ecological regions of Nepal. In each district, 3 municipalities were purposively selected considering access to formal and informal agricultural credit source to farmers in these areas and availability of both formal users and informal users. Informal users are those who have used informal credit and have never obtained any formal credit. Population for this study were farmers who were current agricultural credit users and involved in small holding agricultural practices (less than 0.5 ha farm size) as the major occupation. Sixty (60) smallholder farmers were selected from Lamjung district and 59 smallholder farmers were selected from Nawalpur district by simple random sampling. A total of 119 smallholder farmers were selected in the study area. The household survey was carried out with household head using a pretested semi-structured interview schedule. One (1) Focus Group Discussion (FGD) and 1 Key Informant Interview (KII) was carried out in each municipality to complement the information gathered through household survey.

\section{Empirical Model}

Descriptive analysis and $t$-test was done using SPSS. Probit model was employed using STATA 12.0 in order to determine the factors affecting the use of formal agricultural credit among smallholder farmers. Further, to assess the effect of each independent variable on the smallholder farmers' access to formal agricultural credit, marginal effect on those variables was estimated in the probit model. This model was used to identify the determinants (regressors) on the probability of use of formal agricultural credit (regressand). The likelihood of smallholder farmers' use of formal agricultural credit is a non-linear function of regressors. The probit model used is of the form $\operatorname{Pr}(\mathrm{Y}=1)$ $=\left(\mathrm{X}_{\mathrm{i}}\right)$ where $\operatorname{Pr}(\mathrm{Y}=1)$ represents the probability of use of formal agricultural credit with the change in $\mathrm{X}$ variable. A positive estimated coefficient implies an increase in likelihood of use of formal agricultural credit. Relation between probability values and explanatory variables is established with probit model. It ensures the probability value between 0 and 1 .

Let us suppose $\mathrm{Y}_{\mathrm{i}}$ is the binary response of the smallholder farmers, $Y_{i}=1$, if smallholder farmer use formal agricultural credit, and $Y_{i}=0$ if the smallholder farmer use informal agricultural credit.

If $\mathrm{Y}_{\mathrm{i}}=1 ; \operatorname{Pr}\left(\mathrm{Y}_{\mathrm{i}}=1\right)=\mathrm{P}_{\mathrm{i}}$

If $Y_{i}=0 ; \operatorname{Pr}\left(Y_{i}=0\right)=1-P_{i}$

Where $\mathrm{P}_{\mathrm{i}}=\mathrm{E}(\mathrm{Y}=1 / \mathrm{X})$ represents the conditional mean of $\mathrm{Y}$ given certain values of $\mathrm{X}$.

\section{Model specification}

The probit model specified in this study to analyze factors affecting use of formal agricultural credit among smallholder farmers was expressed as follows.

$\operatorname{Pr}(Y=1)=f\left(b_{0}+b_{1} X_{1}+b_{2} X_{2}+b_{3} X_{3}+b_{4} X_{4}+b_{5} X_{5}+\right.$ $b_{6} X_{6}+b_{7} X_{7}+b_{8} X_{8}+b_{9} X_{9}+b_{10} X_{10}+b_{11} X_{11}+b_{12} X_{12}+$ $\left.b_{13} X_{13}+b_{14} X_{14}+b_{15} X_{15}+b_{16} X_{16}\right)$

where,

$\operatorname{Pr}(Y=1)=$ Probability of use of formal agricultural credit

$\mathrm{X}_{1}=$ Age (continuous)

$\mathrm{X}_{2}=$ Gender (dummy)

$\mathrm{X}_{3}=$ Education (continuous)

$\mathrm{X}_{4}=$ Dependency ratio (continuous)

$\mathrm{X}_{5}=$ Number of adult (continuous)

$\mathrm{X}_{6}=$ Non-agricultural income (dummy)

$\mathrm{X}_{7}=$ Income (continuous)

$\mathrm{X}_{8}=$ Farming experience (continuous)

$\mathrm{X}_{9}=$ Farm size (continuous)

$\mathrm{X}_{10}=$ Contact with extension worker (dummy) 
$\mathrm{X}_{11}=$ Nature of production (dummy)

$\mathrm{X}_{12}=$ Member in organization (dummy)

$\mathrm{X}_{13}=$ Income shock (dummy)

$\mathrm{X}_{14}=$ Livestock (dummy)

$\mathrm{X}_{15}=$ Collateral availability (dummy)

$\mathrm{X}_{16}=$ High value crops (dummy)

$\mathrm{b}_{0}=$ Regression coefficient

$b_{1}, b_{2} \ldots \ldots \ldots b_{16}=$ Probit coefficient

The description of the variables used is presented in Table 1.

\section{Results and Discussion}

\section{Descriptive Statistics}

Summary statistics and explanation of the variables are presented in Table 1. As observed, $66 \%$ of the respondents used formal agricultural credit. The average age of the respondents was 46.54 years. Respondents, on average, had 9.41 years of formal schooling. The average dependency ratio was $54.13 \%$ and average number of adults was 3.29 per household. Also, $64 \%$ of the household received nonagricultural income and had yearly income of NPR 408487.39. The average farming experience and farm size of respondents was 30.88 years and 7.00 ropani respectively. Only $26 \%$ of the respondents had regular contact with the extension worker and $71 \%$ of the respondents were involved in commercial production. Similarly, $98 \%$ of the respondents were involved in organization, $76 \%$ of the respondents had faced income shock and $45 \%$ of the respondents have raised livestock along with crops. Also, $84 \%$ of the respondents have availability of property for collateral and $16 \%$ of the respondents have raised high value crops.

Table 1: Descriptive statistics of the dependent and independent variables used in the study

\begin{tabular}{|c|c|c|c|}
\hline Variable & Description & Mean & $\begin{array}{l}\text { Standard } \\
\text { Deviation }\end{array}$ \\
\hline \multicolumn{4}{|l|}{ Dependent Variable } \\
\hline Use of formal agricultural credit & $\begin{array}{l}=1 \text { if the respondent uses formal agricultural } \\
\text { credit, } 0 \text { otherwise }\end{array}$ & 0.66 & 0.474 \\
\hline \multicolumn{4}{|l|}{ Independent Variables } \\
\hline Age & Age of the respondent (years) & 46.54 & 10.008 \\
\hline Gender & $\begin{array}{l}\text { Gender of the respondent }(=1 \text { if male, } 0 \\
\text { female) }\end{array}$ & 0.72 & 0.450 \\
\hline Education & Years of formal education of the respondent & 9.41 & 3.433 \\
\hline Dependency ratio & Dependency ratio of the household (\%) & 54.13 & 46.180 \\
\hline Number of adults & Number of adults who earn cash in household & 3.29 & 0.774 \\
\hline Non-agricultural income & $\begin{array}{l}=1 \text { if household receive non-agricultural } \\
\text { income, } 0 \text { otherwise }\end{array}$ & 0.64 & 0.482 \\
\hline Income & Yearly income of the household (NPR) & 408487.39 & 255557.34 \\
\hline Farming experience & Farming experience of respondent (years) & 30.88 & 8.545 \\
\hline Farm size & $\begin{array}{l}\text { Own land used for agricultural practices } \\
\text { (ropani) }\end{array}$ & 7.00 & 1.780 \\
\hline Contact with extension worker & $\begin{array}{l}=1 \text { if respondent has regular contact with } \\
\text { extension worker, } 0 \text { otherwise }\end{array}$ & 0.26 & 0.441 \\
\hline Nature of production & $\begin{array}{l}=1 \text { if commercial production, } 0 \text { subsistence } \\
\text { production }\end{array}$ & 0.71 & 0.458 \\
\hline Member in organization & $\begin{array}{l}=1 \text { if respondent is member in non-financial } \\
\text { community organization, } 0 \text { otherwise }\end{array}$ & 0.98 & 0.129 \\
\hline Income shock & $\begin{array}{l}=1 \text { if respondent has faced income shock in } \\
\text { last two years, } 0 \text { otherwise }\end{array}$ & 0.76 & 0.431 \\
\hline Livestock & $\begin{array}{l}=1 \text { if respondent raise livestock along with } \\
\text { crop, } 0 \text { otherwise }\end{array}$ & 0.45 & 0.499 \\
\hline Collateral availability & $\begin{array}{l}=1 \text { if respondent has property for collateral, } 0 \\
\text { otherwise }\end{array}$ & 0.84 & 0.368 \\
\hline High value crop & $\begin{array}{l}=1 \text { if respondent raise high value crop along } \\
\text { with crop, } 0 \text { otherwise }\end{array}$ & 0.16 & 0.368 \\
\hline
\end{tabular}

Source: Field survey (2019)

Note: 9.83 ropani $=0.5$ ha; 1 USD $=113.32 \mathrm{NPR}$ 
The results of differences between means of characteristics describing formal agricultural credit users and informal agricultural credit users are presented in Table 2. There was a significant difference in education, number of adults per household and collateral availability between two groups. Education and collateral availability were significantly higher for formal agricultural credit users compared with informal users. But, number of adults per household was significantly higher in informal agricultural credit users compared with formal users. Additionally, there was no significant difference in other listed characteristics among the groups.

\section{Factors Affecting Use of Formal Agricultural Credit among Smallholder Farmers}

Probit regression analysis was done to assess the factors influencing the use of formal agricultural credit and results are presented in Table 3. Marginal effect was also driven from the regression coefficients as shown in Table 3. Results showed that, seven variables were statistically significant for the use of formal agricultural credit. They were; age, education, number of adults, farming experience, farm size, nature of production and collateral availability. Keeping other factors constant, with increase in age of the respondent by one unit, probability of use of formal agricultural credit will increase by 3.1 percent. This is possibly because of two reasons: firstly, with increase in age, smallholder farmers fell uneasy to ask money from individuals and prefer formal institutions for credit and secondly, with increase in age, smallholders farmer build up own capital and land resources and even receive ancestral property resulting easiness to obtain formal credit. This result is similar to findings of Mamuye (2021). Keeping other factors constant, with increase in education of the respondent by one unit, probability of use of formal agricultural credit will increase by 3.9 percent. This is possibly because of two reasons: firstly, with increase in education, smallholder farmers can access more information related to formal institutions and secondly, with increase in education, smallholder farmers feel confident in legal documentation process. This result is in line with Dzadze et al. (2012); Ibrahim and Alerio (2012); Hussien (2007). Keeping other factors constant, with increase in number of adults in respondent's household by one unit, probability of use of formal agricultural credit will decrease by 16.9 percent. This is possibly because with greater number of adults, household have wider social network and that will help to obtain informal credit easily. Keeping other factors constant, with increase in farming experience of the respondent by one unit, probability of use of formal agricultural credit will decrease by 2.8 percent. This is possibly because with higher farming experience, smallholder farmers have wider social network and that will help to obtain informal credit easily. Keeping other factors constant, with increase in farm size of the respondent by one unit, probability of use of formal agricultural credit will decrease by 8.2 percent. This is possibly because, household having larger farm size are trusted by money lenders and eventually that will help to obtain informal credit easily.

Table 2: Characteristics of formal agricultural credit users and informal agricultural credit users

\begin{tabular}{lllll}
\hline Variables & Formal & Informal & Difference & t-value \\
\hline Age & 47.04 & 45.55 & 1.488 & 0.765 \\
Gender & 0.76 & 0.65 & 0.109 & 1.258 \\
Education & 9.91 & 8.43 & 1.486 & $2.270^{* *}$ \\
Dependency ratio & 54.4301 & 53.5412 & 0.888 & 0.099 \\
Number of adults & 3.20 & 3.48 & -0.272 & $-1.832^{*}$ \\
Income & 434683.54 & 356750.00 & 77933.544 & 1.581 \\
Farming experience & 30.85 & 30.95 & -0.102 & -0.061 \\
Farm size & 6.905 & 7.200 & -0.2949 & -0.852 \\
Contact with extension & 0.28 & 0.23 & 0.053 & 0.624 \\
worker & & & 0.122 & 1.377 \\
Nature of Production & 0.75 & 0.63 & 0.012 & 0.491 \\
Member in organization & 0.99 & 0.98 & -0.066 & -0.785 \\
Income shock & 0.73 & 0.80 & -0.007 & -0.072 \\
Livestock & 0.44 & 0.45 & 0.249 & $3.669 * * *$ \\
Collateral availability & 0.92 & 0.68 & 0.015 & 0.203 \\
High value crops & 0.16 & 0.15 & &
\end{tabular}

Source: Field survey (2019)

Note: $* * *, * *, *$ indicate significant at $1 \%, 5 \%, 10 \%$ level of significance, respectively. 
Table 3: Probit regression analysis and marginal effect for factors affecting the use of formal agricultural credit Source: Field survey (2019)

\begin{tabular}{|c|c|c|c|c|c|}
\hline Variables & Coefficient & $p$-value & S.E. & $\mathrm{dy} / \mathrm{dx}$ & S.E. $(d y / d x)$ \\
\hline Age & $0.093 * *$ & 0.026 & 0.041 & 0.031 & 0.013 \\
\hline Gender & 0.145 & 0.646 & 0.317 & 0.050 & 0.111 \\
\hline Education & $0.116 * *$ & 0.022 & 0.050 & 0.039 & 0.017 \\
\hline Dependency ratio & -0.004 & 0.305 & 0.003 & -0.001 & 0.001 \\
\hline Number of adults & $-0.498 * *$ & 0.047 & 0.250 & -0.169 & 0.084 \\
\hline Non-agricultural income & 0.554 & 0.107 & 0.344 & 0.194 & 0.122 \\
\hline Log-income & 0.495 & 0.384 & 0.569 & 0.168 & 0.192 \\
\hline Farming experience & $-0.084 *$ & 0.087 & 0.049 & -0.028 & 0.016 \\
\hline Farm size & $-0.243 * * *$ & 0.008 & 0.092 & -0.082 & 0.031 \\
\hline Contact with extension worker & -0.055 & 0.882 & 0.374 & -0.019 & 0.129 \\
\hline Nature of production & $0.567^{*}$ & 0.068 & 0.311 & 0.202 & 0.113 \\
\hline Member in organization & -0.232 & 0.817 & 1.001 & -0.073 & 0.292 \\
\hline Income shock & -0.374 & 0.270 & 0.339 & -0.119 & 0.101 \\
\hline Livestock & -0.280 & 0.427 & 0.353 & -0.096 & 0.121 \\
\hline Collateral availability & $1.588 * * *$ & 0.000 & 0.431 & 0.563 & 0.129 \\
\hline High value crop & -0.149 & 0.726 & 0.427 & -0.052 & 0.153 \\
\hline Constant & 2.925 & 0.343 & 3.008 & -2.925 & \\
\hline \multicolumn{6}{|l|}{ Summary statistics } \\
\hline \multicolumn{6}{|l|}{ Log likelihood $=-54.735$} \\
\hline \multicolumn{6}{|l|}{$\operatorname{LR} \operatorname{chi}^{2}(16)=42.48$} \\
\hline \multicolumn{6}{|l|}{ Prob $>$ chi $^{2}=0.0003$} \\
\hline \multicolumn{6}{|l|}{ Pseudo $\mathrm{R}^{2}=0.2796$} \\
\hline \multicolumn{6}{|l|}{ Number of observation $(\mathrm{N})=119$} \\
\hline
\end{tabular}

Keeping other factors constant, if respondent has commercial production, probability of use of formal agricultural credit will increase by 20.2 percent. This is possibly because formal institutions provide attractive credit facilities to smallholder farmers involved in commercial agriculture. Keeping other factors constant, if respondent has availability of property for collateral, probability of use of formal agricultural credit will increase by 56.3 percent. This is possibly because major formal institutions provide credit on the basis of collateral. This result is similar to findings of Ibrahim and Alerio (2012).

\section{Conclusion}

The result shows that $66 \%$ of the sampled household used agricultural credit from formal institutions. This means that the formal institutions need to perform relatively well to involve more smallholder farmers in its system. Older and educated smallholder farmers were using more formal agricultural credit. This implies formal institutions should initiate special credit programs to older and educated ones for better utilization. Household having less number of adult were using more formal credit. This implies formal institutions should focus primarily on household with less working forces for better credit utilization. Smallholder farmers having less farming experience were using more formal credit. This means formal institutions should come up with special credit facilities for someone new in farm practices. Household having less farm size were using more formal agricultural credit. This implies formal institutions should focus on smallholder farmers in its core programs for better utilization. Smallholder farmers involving in commercial agriculture and having availability for collateral were using more formal agricultural credit. This implies formal institution should emphasize on commercial farmers and farmers having availability for collateral for better credit utilization. Hence, government should integrate these factors in policies to improve formal agricultural credit market.

\section{Author's Contribution}

All works are done alone by the author.

\section{Conflict of Interest}

No conflict of interest with the present work.

\section{References}

Central Bureau of Statistics (CBS) (2011) Nepal Living Standard Survey 2010/11. Statistical Report, Volume II. Central Bureau of Statistics, National Planning Commission Secretariat. November, 2011. Government of Nepal. National Planning Commission Secretariat. November 2012. 
Dzadze P, Aidoo R and Nurah GK (2012) Factors determining access to formal credit in Ghana: A case study of smallholder farmers in the Abura-Asebu Kwamankese district of central region of Ghana. Journal of Development and Agricultural Economics 4(14): 416-423.

Goldsmith R (1969) Financial Structure and Development. New Haven: Yale University Press.

Hussien H (2007) Farm Household Economic Behaviour in Imperfect Financial Markets, Doctoral Thesis. Uppsala: Swedish University of Agricultural Sciences.

Ibrahim SS and Aliero HM (2012) An analysis of farmers access to formal credit in the rural areas of Nigeria. African journal of agricultural research 7(47): 6249-6253. DOI: $\underline{10.5897 / A J A R 11.788}$

Lemessa A and Gemechu A (2016) Analysis of factors affecting smallholder farmers' access to formal credit in Jibat District, West Shoa Zone, Ethiopia. International Journal of African and Asian Studies 25: 43-53.
Mamuye W (2021) Determinants of Smallholder Farmers Participation in Formal Credit and Challenges Faced by Institutions: The Case of Mojana Wodera District, Amhara Region, Ethiopia. International Journal of Finance and Banking Research 7(1): 9. DOI: $\underline{10.11648 / j . i j f b r .20210701 .12}$

McKinnon R (1973) Money and Capital in Economic Development. Washington, D.C.: Brookings Institution.

Mohieldin MS and Wright PW (2000) Formal and informal credit markets in Egypt. Economic development and cultural change 48(3): 657-670. DOI: 10.1086/452614

Oni O, Nkonya E, Pender J, Phillips D and Kato E (2009) Trends and drivers of agricultural productivity in Nigeria. Nigeria Strategy Support Program (NSSP) Report 001. International Food Policy Research Institute.

Shaw E (1973) Financial Deepening in Economic Development. New York: Oxford University Press. 